\title{
Teoreticko-metodologické východiská monetárneho a nemonetárneho hodnotenia ekosystémových služieb
}

Theoretical and methodological basis of monetary and non-monetary valuation of ecosystem services

\section{Bianka Slašt’anová, Stanislav Kološta, Jarmila Makovníková}

Abstract: Ecosystem services (ES) are essential for survival of society and contribute to human well-being, employment and the functioning of many economic sectors. The aim of the article was to evaluate monetary and non-monetary methods of ES evaluation. It is a theoretical and methodological study based on a synthesis of the most important experiences and methodologies used within ES evaluation. Research studies show that the evaluation of goods and services provided by ecosystems is increasingly used in spatial planning, ecosystem management, creation of strategic documents, assessment of synergies and tradeoffs from relations between individual ES. Future research within ES valuation should benefit from close cooperation of social sciences and natural sciences, which have the prospect of discovering new perspectives and approaches to ES assessment, taking into account the importance of their preservation for future generations..

Key words: Ecosystem services. Valuation. Monetary.

JEL Classification: Q57.

\section{Úvod}

Za najjednoduchšiu definíciu ekosystémových služieb (d'alej ES) možno považovat' definíciu TEEB (2010) - „ekosystémové služby sú priame a nepriame príspevky ekosystémov k l’udskému blahobytu“. ES sú nevyhnutné pre prežitie spoločnosti a taktiež prispievajú k blahobytu, zabezpečeniu kvality života a významne prispievajú k zamestnanosti a k funkčnosti mnohých hospodárskych sektorov. Jednou z kl'účových ES podiel'ajúcich sa na ekonomickej činnosti a zamestnanosti je produkcia potravín, ktorá od roku 2000 predstavuje 3\% svetového HDP, výrazne vyšší podiel sa odhaduje v rozvojových krajinách (MAE, 2005). 
ES priamo súvisia so životnou úrovňou l'udí a ich znehodnotenie znižuje kvalitu l’udského blahobytu, ktorého určujúce prvky sú priamo previazané s ES (obrázok 1).

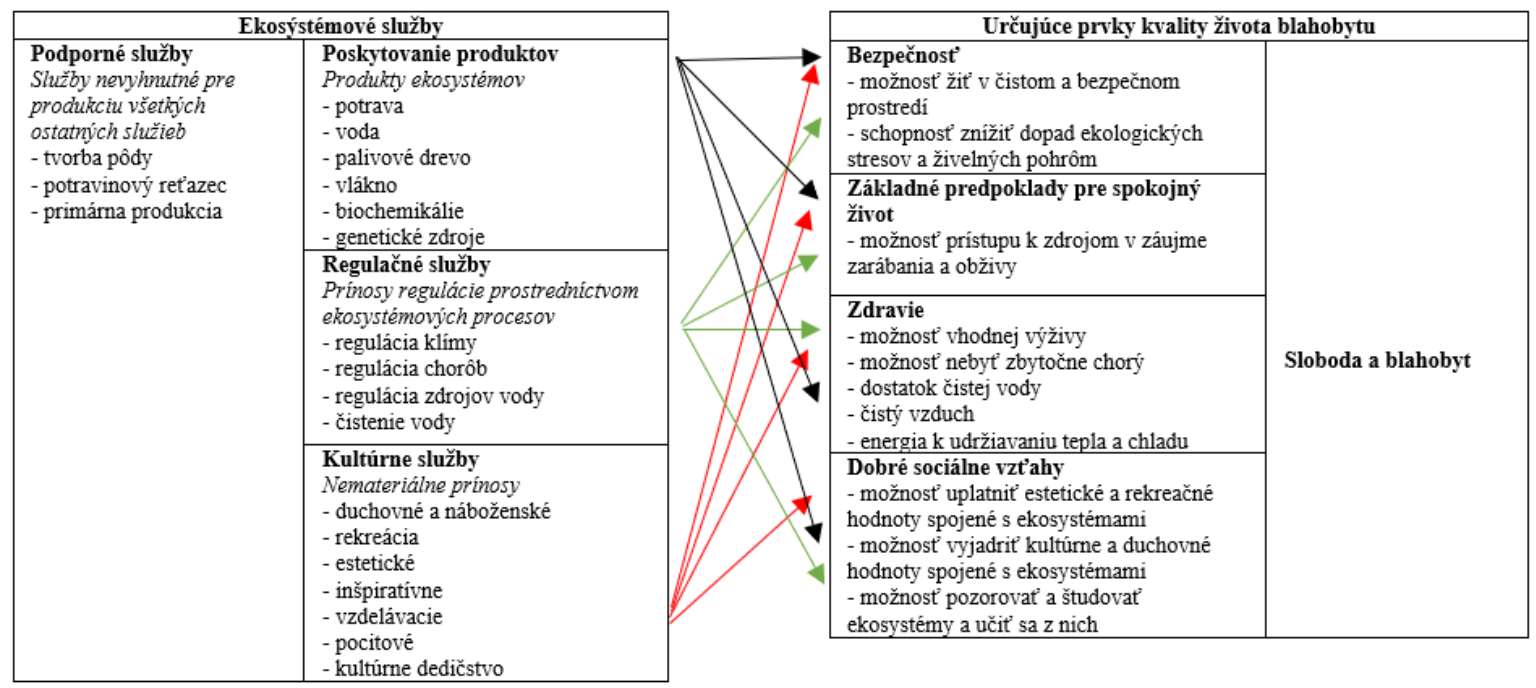

Obrázok 1 Previazanost' ekosystémových služieb s l'udským blahobytom Zdroj : Spracované podl'a MAE (2005).

Zatial' čo dopyt po ES narastá, l'udské aktivity súčasne znižujú schopnost' mnohých ekosystémov poskytovat' ekosystémové služby. Činnost' človeka ničí biodiverzitu, čo má dopad na znižovanie odolnosti zdravých ekosystémov poskytovat' široké rozpätie služieb a tovarov. Pre udržatel'ný život je nevyhnutné zaistit' minimálnu úroveň ekologických zásob, tzv. ekologickú bezpečnost' (MAE, 2005). Tieto dôvody vyvolávajú potrebu hodnotenia a ocenenia ES už viac ako štvrt'storočie.

\section{Ciel', materiál a metódy skúmania}

Ciel'om článku je zhodnotit' monetárne a nemonetárne spôsoby hodnotenia ekosystémových služieb. Jedná sa o teoreticko-metodologickú štúdiu vychádzajúcu zo syntézy najpodstatnejších skúseností a metodík používaných pri hodnotení ES. Ide o dynamicky rozvíjajúcu sa oblast' výskumu, ktorého výsledky môžu byt' prínosom v podobe ich zakomponovania v rámci spoločensko-vedných výskumov.

\section{2 Členenie ekosystémových služieb a ich funkcií}

Na medzinárodnej úrovni je široko akceptovaná kategorizácia ES podl’a Costanza et al. (1997) a Miléniového posudzovania ekosystémov (MAE, 2005) rozlišujúca štyri hlavné skupiny ES: 1. zásobovacie služby (provízne služby, ekosystémové statky), 2. regulačné služby (úžitky vytvorené samo-udržujúcimi schopnost'ami ekosystémov), 3. kultúrne služby 
(nemateriálne úžitky odvodené $\mathrm{z}$ ekosystémov) a 4. podporné služby (nevyhnutné na produkciu a udržanie všetkých iných ES). ES naviazané na prírodný kapitál delí Dominati et al. (2010) do troch základných skupín a to zásobovacie, regulačné a kultúrne služby a k nim prirad’uje podporné procesy nevyhnutné na udržanie ES. Ekosystémové tovary a služby predstavujú výhody, ktoré obyvatel'stvo čerpá priamo alebo nepriamo z ekosystémových funkcií. Costanza et al. (1997) vo svojej publikácií The value of the world's ecosystem services and natural capital uviedli celkovú finančnú hodnotu služieb ekosystémov (hodnotili 17 ekosystémových služieb), pričom zahrnuli iba obnovitel'né ES a vyradili neobnovitel'né palivá, minerály a atmosféru; túto štúdiu možno považovat' za priekopnícku a dodnes inšpiratívnu (tabul'ka 1).

Tabul'ka 1 Rozdelenie ekosystémových služieb a ich funkcií

\begin{tabular}{|c|c|c|}
\hline Ekosystémové služby & Ekosystémové funkcie & Príklady \\
\hline 1. Regulácia ovzdušia & $\begin{array}{l}\text { Regulovanie chemického zloženia } \\
\text { atmosféry, udržanie chemického } \\
\text { zloženia atmosféry }\end{array}$ & $\begin{array}{l}\text { Stabilizácia } \mathrm{CO}_{2} \text { a } \mathrm{O}_{2}, \mathrm{O}_{3} \text { pre ochranu povrchu } \\
\text { Zeme pred UV žiarením }\end{array}$ \\
\hline 2. Klimatická regulácia & $\begin{array}{l}\text { Regulovanie globálnej teploty, } \\
\text { zrážok a d'alších sprostredkovaných } \\
\text { procesov v spoločnosti na globálnej } \\
\text { alebo lokálnej úrovni }\end{array}$ & $\begin{array}{l}\text { Regulácia skleníkových plynov, produkcia } \\
\text { DMS (dimethylsulfid), ovplyvnenie tvorby } \\
\text { oblačnosti }\end{array}$ \\
\hline $\begin{array}{l}\text { 3. Tlmenie mimoriadnych } \\
\text { prírodných } \\
\text { udalostí }\end{array}$ & $\begin{array}{l}\text { Kapacita, tlmenie a integrita } \\
\text { ekosystémov, reakcia na výkyvy } \\
\text { v prírode }\end{array}$ & $\begin{array}{l}\text { Ochrana pred búrkami, protipovodňová } \\
\text { ochrana, regenerácia po suchu, kontrola } \\
\text { variability prírodných udalostí }\end{array}$ \\
\hline 4. Regulácia vôd & Regulácia hydrologických tokov & $\begin{array}{l}\text { Regulácia vôd pre pol'nohospodárstvo, } \\
\text { priemysel, dopravu a iné odvetvia }\end{array}$ \\
\hline 5. Zásobovanie vodou & Ukladanie a retencia vody & Používanie vody z povodia, nádrží atd'. \\
\hline $\begin{array}{l}\text { 6. Kontrola erózie a } \\
\text { zadržiavanie } \\
\text { sedimentov }\end{array}$ & Zadržiavanie pôdy & $\begin{array}{l}\text { Prevencia straty pôdy } \mathrm{v} \text { dôsledku veternej, } \\
\text { vodnej erózie a d'alšími rozrušovacími } \\
\text { procesmi, ukladanie sedimentov v jazerách a } \\
\text { mokradiach }\end{array}$ \\
\hline 7. Tvorba pôdy & Proces formovania pôdy & $\begin{array}{l}\text { Zvetrávanie hornín a hromadenie organického } \\
\text { materiálu }\end{array}$ \\
\hline $\begin{array}{l}\text { 8. Kolobeh minerálnych } \\
\text { živín }\end{array}$ & $\begin{array}{l}\text { Skladovanie, vnútorný cyklus, } \\
\text { spracovanie a získavanie živín }\end{array}$ & $\begin{array}{l}\text { Fixácia, uvol'ňovanie, cyklus dusíka, N, P a } \\
\text { d'alších prvkov }\end{array}$ \\
\hline 9. Odpadové hospodárstvo & $\begin{array}{l}\text { Obnova a odstránenie živín alebo } \\
\text { rozptyl prebytku živín a zlúčenín }\end{array}$ & $\begin{array}{l}\text { Nakladanie s odpadmi, } \\
\text { znečist'ovania, detoxikácia }\end{array}$ \\
\hline 10. Opel'ovanie & Rozširovanie kvetových gamét & $\begin{array}{l}\text { Podpora opel'ovačov pre rozmnožovanie } \\
\text { rastlín }\end{array}$ \\
\hline 11. Biologická kontrola & $\begin{array}{l}\text { Troficko-dynamická } \\
\text { populácií }\end{array}$ & $\begin{array}{l}\text { Regulácia trofického ret’azca, regulácia } \\
\text { bylinožravých organizmov, predátorov a pod. }\end{array}$ \\
\hline 12. Refúgia & $\begin{array}{l}\text { Stanovište pre rôzne druhy a } \\
\text { prechodné populácie }\end{array}$ & $\begin{array}{l}\text { Škôlky, stanovištia pre st'ahovavé druhy, } \\
\text { regionálne stanovištia pre lokálne lovené } \\
\text { druhy, prezimovanie druhov }\end{array}$ \\
\hline 13. Potravinová produkcia & Jedlo získané z hrubej prvovýroby & $\begin{array}{l}\text { Produkcia rýb, diviny, plodín, orechov, } \\
\text { ovocia, možnost' lovu, pol'nohospodárstva a } \\
\text { rybolovu }\end{array}$ \\
\hline 14. Produkcia surovín & $\begin{array}{llll}\begin{array}{l}\text { Suroviny získané } \\
\text { prvovýroby }\end{array} & \text { z } & \text { hrubej } \\
\end{array}$ & Výroba reziva, paliva a krmív \\
\hline 15. Genetické zdroje & $\begin{array}{l}\text { Zdroje jedinečných biologických } \\
\text { materiálov a produktov }\end{array}$ & $\begin{array}{l}\text { Medicína, produkty pre vedecké materiály, } \\
\text { gény odolné proti rastlinným patogénom a } \\
\text { škodcom plodín, okrasné druhy (domáce }\end{array}$ \\
\hline
\end{tabular}




\begin{tabular}{|l|lr|l|}
\hline 16. Rekreácia & \multicolumn{2}{|c|}{ zvieratá a záhradnícke odrody rastlín) } \\
\hline 17. Kultúra & $\begin{array}{l}\text { Poskytovanie príležitostí pre } \\
\text { rekreačné aktivity }\end{array}$ & $\begin{array}{l}\text { Eko-turistika, športový rybolov a d'alšie } \\
\text { outdoorové rekreačné aktivity }\end{array}$ \\
\hline & $\begin{array}{l}\text { Poskytovanie príležitostí } \\
\text { nekomerčné využitie }\end{array}$ & pre & $\begin{array}{l}\text { Estetické, umelecké, výchovné, duchovné a } \\
\text { vedecké hodnoty ekosystémov }\end{array}$ \\
\hline
\end{tabular}

Zdroj: Spracované podl'a Costanza et al. (1997).

Od roku 1997 sa globálna hodnota ES (terestriálneho ekosystému) odhadovala na základe zmien využívania pôdy ako hlavného parametra, a to v priemere na $33 \$$ biliónov ročne; v roku 2007 hodnota stúpla na $\$ 46$ biliónov ročne a v roku 2011 až na $\$ 125$ biliónov ročne (Constanza et al., 2014). ES tak prispievajú k l’udskému blahobytu dvakrát viac ako globálne HDP. Jednou z metód hodnotenia zmien využitia pôdy je využitie dial'kového snímania s priestorovým rozlíšením $1 \mathrm{~km} 2$. Výskumy ukazujú, že podl’a rôznych scenárov môže globálna hodnota ES, bud' klesnút' o 51 biliónov USD ročne, alebo sa môže dokonca aj zvýšit' o 30 biliónov USD ročne. Hodnota globálnych ES sa tak podl’a viacerých scenárov môže do roku 2050 líšit' medziročne o 81 biliónov dolárov (Kubiszewski et al., 2017).

\section{Vyjadrenie hodnoty ekosystémových služieb}

Spoločnost' profituje z ES vtedy, ked' produkcia prináša úžitok. Tieto benefity je možné kvantifikovat' ich monetárnou alebo nemonetárnou hodnotou. Napriek úsiliu odhadnút' hodnotu ES monetárnymi metódami, väčšina systémov na podporu environmentálnych politík používa nemonetárne oceňovacie prístupy (Pandey, 2016). Okrem ekonomickej analýzy a konceptu celkových ekonomických hodnôt môžeme hodnotu ES vyjadrit' z biofyzikálneho a geochemického hl'adiska prostredníctvom prírodných vied alebo pomocou kvalitatívnych hl'adísk - napr. prostredníctvom sociológie, kultúrnej geografie, umenia, humanitných vied (Bandura et al., 2016). Ekologická, sociokultúrna a ekonomická funkcia ekosystémov predstavuje tri základné faktory pre určovanie hodnoty ES. Podl'a Gómez-Baggethum et al. (2016) je ciel'om hodnotenia ES dosiahnutie environmentálnej udržatel'nosti, sociálnej spravodlivosti a dlhodobej ekonomickej životaschopnosti.

Nakol'ko je možné hodnotu ES vyjadrit' rôznymi metódami, peňažné vyjadrenie predstavuje dôležitý nástroj na zvýšenie povedomia o význame ekosystémov a biodiverzity $\mathrm{v}$ rámci formulovania verejných politík. Zefektívnenie využívania limitovaných finančných prostriedkov je možné dosiahnut' pomocou informácií o peňažných hodnotách, ktoré poukazujú na to, kde je ochrana a obnova ekosystémov a biodiverzity ekonomicky najviac potrebná a kde môže byt’ poskytnutá pri najnižších nákladoch (Crossman, Bryan, 2009). Podla Farleyho et al. (2008) vyjadrenie hodnôt ES v peňažných jednotkách poskytuje návod 
na pochopenie preferencií súčasných generácií, ktoré ich spotrebúvajú, čo umožňuje lepšie alokovat' zdroje medzi konkurenčnými úžitkami. Potrebné je uvedomit' si, že monetárne oceňovanie založené na trhových cenách zvyčajne neodráža práva ani hodnoty budúcich generácií. Metódy hodnotenia a ocenenia ES používajú prevažne odhady založené na trhových a netrhových hodnotách, mnohé sú založené na priamych alebo nepriamych metódach odhadu individuálnej hodnoty ekosystému na základe „willinges-to-pay“, čiže ochoty platit’ za ES (Costanza et al., 1997). Hodnotenie tovarov a služieb poskytovaných ekosystémami je čoraz častejšie využívané pri územnom plánovaní. Podl’a Čemeckého et al. (2020) hodnotenie ES vieme rozdelit' do dvoch základných skupín a to na monetárne a nemonetárne metódy. Integrované metódy (Constanza, 2017; Makovníková et al., 2019) predstavujú kombináciu viacerých postupov a prepájajú rôzne metódy hodnotenia ES.

\subsection{Nemonetárne metódy hodnotenia ekosystémových služieb}

Hodnotenie ES nepeňažnými spôsobmi má svoje využitie vo viacerých oblastiach environmentálnej politiky a v poslednom desat'ročí rôzne medzinárodné iniciatívy potvrdili jeho úlohu v oceňovaní ES (napr. MAE, TEEB, IPBES). Napriek rastúcemu vedeckému záujmu a politickému tlaku, nepeňažné hodnotenie využíva len neformalizované indikátory (Seppelt et al., 2014).

Biofyzikálne metódy hodnotenia ES (obrázok 2) sú merané kvantifikáciou toku materiálov a energie $\mathrm{v}$ biofyzikálnych jednotkách. Vyžadujú si pravidelné meranie indikátorov toku ES, ktoré vychádzajú zo zásob prírodného kapitálu, ktoré tvoria potenciál ES (Dominanti, et al., 2010). Vo všeobecnosti možno konštatovat', že čím je rozlohovo väčšia zásoba prírodného kapitálu $\mathrm{v}$ podobe kvalitných pôd a lesných porastov, tým je väčší potenciál krajiny poskytovat' ES pre súčasné aj budúce generácie.

Jednou z biofyzikálnych metód je aj „maticová metóda“, ktorá využíva expertný odhad bodovej hodnoty jednotlivých služieb na detailné hodnotenie služieb ekosystémov (Burkhard et al., 2014). Pre hodnotenie ES Slovenska bol použitý ekosystémový prístup (Černecký et al., 2019), ktorý modifikoval hodnotiacu maticu na základe stavu ekosystému, pretože len zdravé ekosystémy sú schopné poskytovat' služby v plnej miere. Maticový model má potenciál integrovat' všetky druhy údajov: od expertných výsledkov po štatistické, údaje z rozhovorov, meraní, či špecializované výstupy, ktoré ho robia aplikovatel’ným v prostredí, kde je málo údajov alebo naopak v prostredí bohatom na údaje. $\mathrm{V}$ neposlednom rade, výsledky založené na flexibilnom systéme hodnotenia a ich prepojenie na geofyzikálne priestorové jednotky (ako 
napr. land cover, biotopy, vegetácia, pôdne typy) v mapách ES poskytujú široké spektrum aplikácie vo vede a v manažérskom či politickom rozhodovaní.

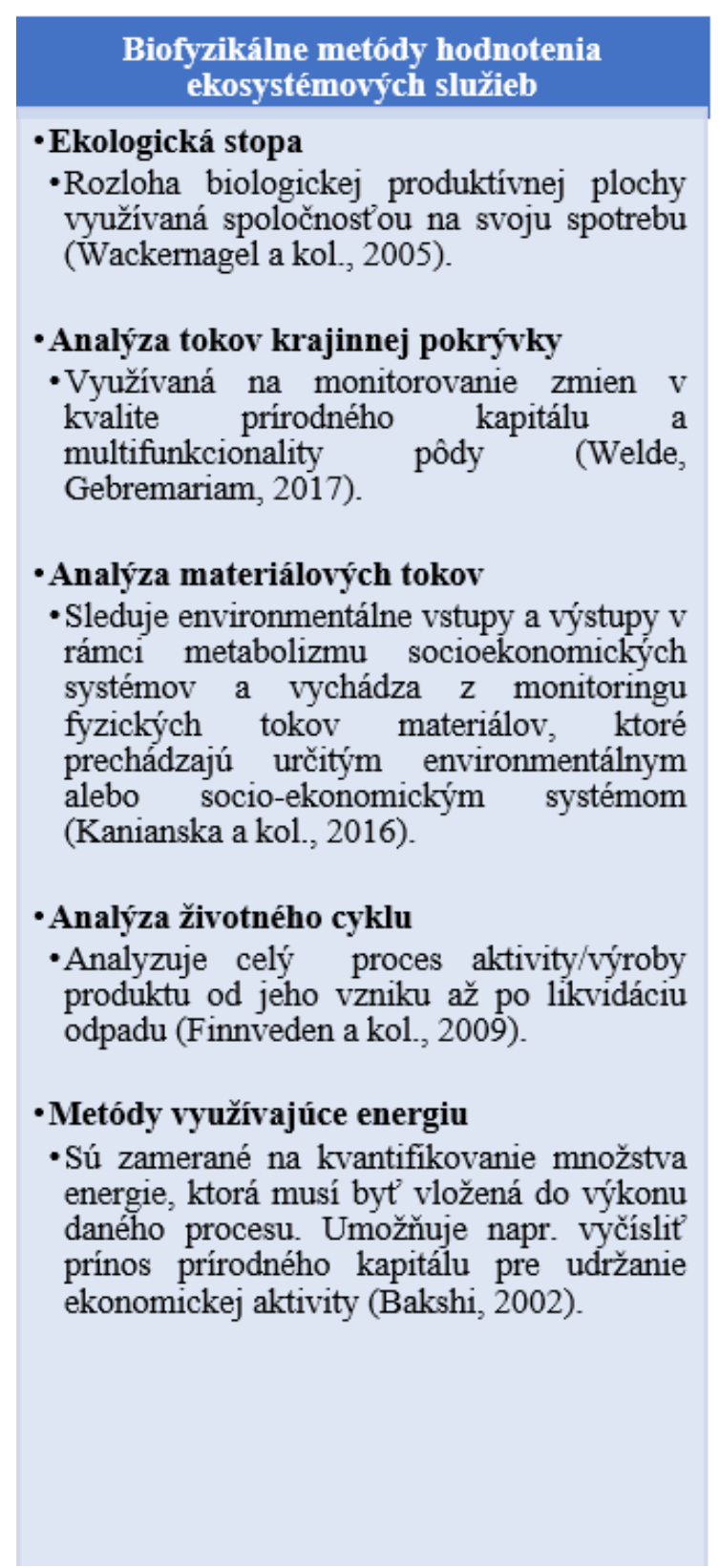

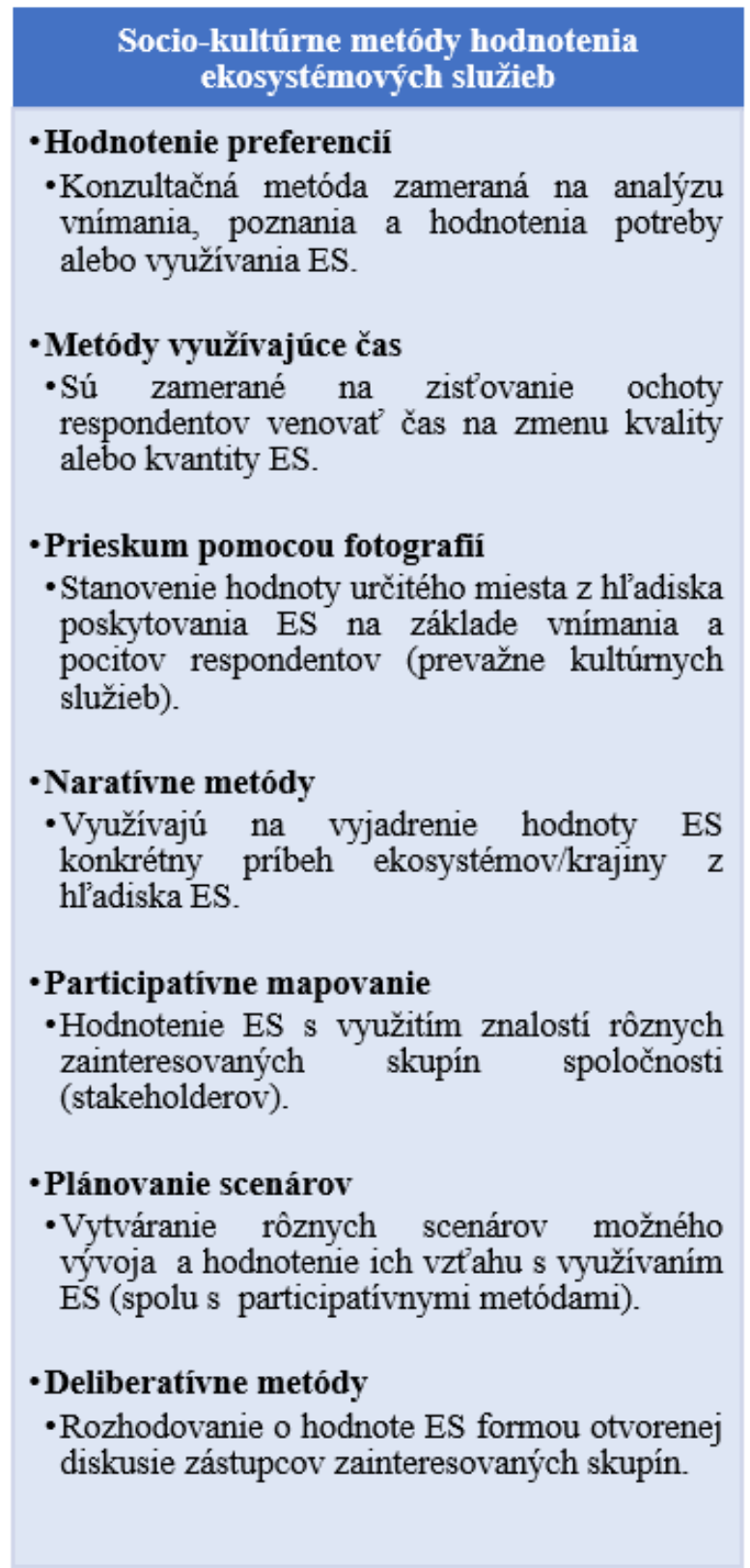

Obrázok 2 Biofyzikálne a socio-kultúrne metódy hodnotenia ekosystémových služieb Zdroj: Spracované podl'a Mederly, Černecký et al. (2019), Santos-Martín et al. (2018).

Ekologické (biofyzikálne) hodnotenie je zvyčajne prvým krokom hodnotenia ES. Zameriava sa predovšetkým na hodnotenie stavu a fungovania ekosystémov a ich vlastností, od ktorých sa následne odvíjajú aj hodnoty sociálne a ekonomické. Obrázok 2 obsahuje charakteristiku najčastejšie využívaných socio-kultúrnych nemonetárnych metód hodnotenia ES, ktoré sú charakteristické tým, že zbierajú vstupné údaje od zainteresovaných stakeholderov na základe ich vnímania skúmaných oblastí ES. Vo väčšej miere sa využíva zber primárnych údajov vo forme dotazníkov a riadených rozhovorov. 


\subsection{Monetárne metódy hodnotenia ekosystémových služieb}

V súčasnej globálnej ekologickej kríze narastá potreba hodnotenia ekosystémovej funkcie podpory blahobytu človeka, určenia postupov a politík manažmentu území, ktoré môžu pomôct' dosiahnut' ciele udržatel'ného rozvoja spoločnosti (Brand et al., 2020). Z širšieho uhla pohl'adu, ekonomické metriky spojené s ES zahŕňajú ekonomické blaho, národný dôchodok, zamestnanost', produktivitu faktorov, konkurencieschopnost', chudobu, závislost' od zdrojov, nerovnost' $v$ príjmoch a d'alšie (Banerjee et al., 2020). Peňažné oceňovanie ES umožňuje efektívnu alokáciu zdrojov pre potreby udržatel'ného riadenia spoločnosti (Heckwolf et al., 2021).

Peňažné oceňovanie ES je ukazovatel'om výšky príjmu, ktorej občania sú ochotní sa vzdat', v prospech získania d’alšej jednotky ES bez toho, aby došlo k jej znehodnoteniu. Práve z tohto dôvodu chápeme marginálnu hodnotu ES pre verejný statok spoločnosti ako ekvivalentnú k zmenám v individuálnych príjmoch (Zanchi, Brady, 2019). De Groot et al. (2012) považujú monetárne hodnotenie ES za dôležitý nástroj na integrovanie povedomia o význame a hodnote ekosystémov, biodiverzity a ES do verejných politík. Monetárne oceňovanie založené na trhových cenách nemusí však reflektovat' hodnoty budúcich generácií. Nákladové metódy spadajúce pod peňažné spôsoby hodnotenia ES sa používajú aj na oceňovanie hodnôt ekosystémov založených na prípadoch, ked’ je ekosystém degradovaný a nemôže $v$ dostatočnej miere poskytovat' ES. Na ocenenie sa využíva hodnota nákladov alternatívneho zabezpečenia ES.

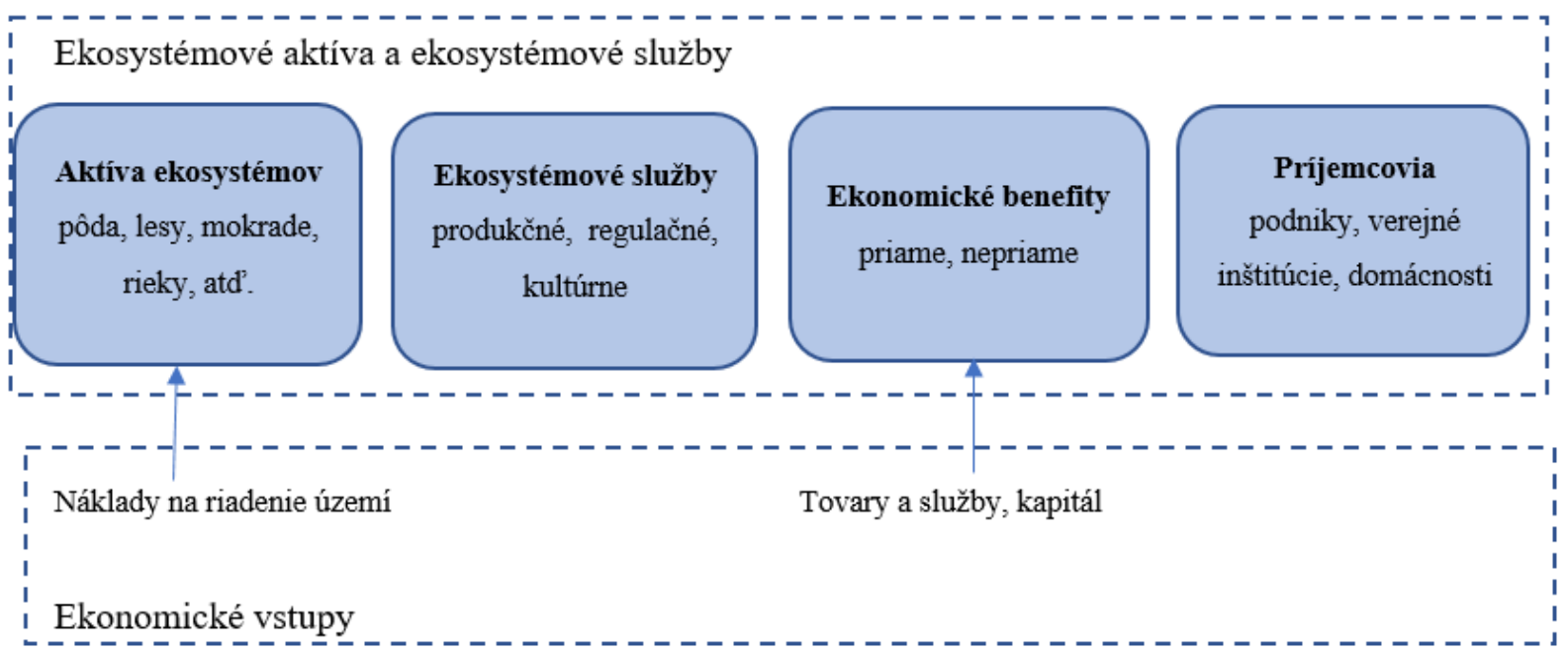

Obrázok 3 Kl'účové komponenty monetárneho oceňovania ekosystémových služieb Zdroj: Spracované podl'a Horlings et al. (2020).

Kl'účové komponenty monetárneho oceňovania ES ilustruje obrázok 3. Znázorňuje logický ret’azec, na začiatku ktorého sú fungujúce ekosystémy poskytujúce príjemcom priame 
benefity (tovary a služby produkované ekonomickými jednotkami využívajúce ES ako priame vstupy; napr. ovocný sad) a nepriame benefity (všeobecne nepotrebujú priamy vstup vo forme práce alebo kapitálu; napr. činnost' opel'ovačov zvyšujúcich priemernú úrodu ovocných sadov).

Klasifikácia trhového hodnotenia ES je podl'a De Groot et al. (2002) rozdelená do štyroch základných skupín: priame trhové hodnotenie, nepriame trhové hodnotenie, kontigentné trhové hodnotenie, skupinové hodnotenie. Iné rozdelenie do dvoch základných skupín uvádza Seják et al. (2003): preferenčný prístup založený na stanovených preferenciách, nepreferenčný prístup založený na experimentálnom zist'ovaní nákladov a rizík. Najčastejšie využívané preferenčné metódy sú charakterizované v tabul'ke 2. 
Tabul'ka 2 Preferenčné metódy trhového oceňovania ekosystémových služieb

\begin{tabular}{|l|l|}
\hline Metóda & Charakteristika \\
\hline $\begin{array}{l}\text { Metóda kontingenčného } \\
\text { oceňovania }\end{array}$ & $\begin{array}{l}\text { Využívaná najmä pre oceňovanie rekreačných a krajinno-estetických } \\
\text { funkcií formou štruktúrovaného dotazníka (Tutka et al., 2011). }\end{array}$ \\
\hline Metóda hedonického oceňovania & $\begin{array}{l}\text { Založená na nepriamom oceňovaní ES prostredníctvom súvisiacich } \\
\text { trhov, pričom sa pri ES využíva vzt'ah medzi cenami prírodného } \\
\text { kapitálu (pôdy) a zmenou hodnoty ES (Seják et al., 2003). }\end{array}$ \\
\hline Metóda cestovných nákladov & $\begin{array}{l}\text { Založená na analýze nákladov, ktoré jednotlivec vynakladá na cestu za } \\
\text { danou službou, ktorá sa využíva najmä na oceňovanie kultúrnych } \\
\text { a rekreačných služieb ekosystému (Moravč́́k et al., 2008). }\end{array}$ \\
\hline Metóda substitučných nákladov & $\begin{array}{l}\text { Náklady nevyhnutné na obnovenie ekosystémov a ich služieb, alebo } \\
\text { náklady na vytvorenie náhradných služieb (napr. investície do } \\
\text { infraštruktúry na ochranu brehov riek namiesto udržiavania prirodzenej } \\
\text { brehovej vegetácie (Považan et al., 2014). }\end{array}$ \\
\hline Metóda odvrátených nákladov & $\begin{array}{l}\text { Náklady, ktoré by sa ušetrili, keby sa nerealizovali aktivity, ktoré vedú } \\
\text { k znehodnoteniu a stratám ES (Považan et al., 2014). }\end{array}$ \\
\hline
\end{tabular}

Zdroj: Vlastné spracovanie.

Trhové nástroje využívané pri hodnotení ES sú považované za politické prostriedky, ktorých ciel'om je pozitívne stimulovat' starostlivost' o životné prostredie. Zarad'ujeme sem tie ekonomické nástroje, ktoré používajú ceny alebo iné ekonomické ukazovatele - napr. finančné stimuly na: redukovanie škôd, ochranu poškodzovania ekosystémov, podporu vhodnejších environmentálnych praktík (výnosovo orientované metódy, nákladovo orientované metódy; Chobotová, 2010).

Monetárne hodnotenie ES má svoje pozitíva aj negatíva. Hoci väčšina autorov jeho potrebu uznáva (najmä ako nástroja na zvyšovanie povedomia, prípadne na porovnanie nákladov rôznych alternatív pre zlepšenie poskytovania ES), čast' vedcov užitočnost' ekonomického hodnotenia ES spochybňuje. Napríklad podl’a Spangenberga a Setteleho (2010) monetárne hodnotenie ES nedokáže zachytit’ hodnotu ES v širšom zmysle a ignoruje tak ich sociálne a ekologické kvality, ktoré vnímajú príjemcovia ES na rôznych úrovniach. Norgaard (2000) uvádza, že monetárne metódy hodnotenia väčšinou iba pomáhajú vidiet' hodnoty ES z pohl'adu neudržatel’nej ekonomiky a nie z pohl'adu ,žiaduceho“ udržatel'ného ekonomického modelu. Často diskutovaný je aj etický rozmer hodnotenia služieb prírody (napr. Chan, Liao, 2016). Celkovo teda rezonuje potreba zasadit' ekonomické hodnotenie do širšieho kontextu hodnotenia ES ako podporného nástroja pre posun smerom k udržatel'nej spoločnosti.

ES vo vel'kej miere existujú mimo tradičné trhy. Tradičné hodnotenia sa zameriavajú na ekonomickú hodnotu ekosystémov, ktorú porovnávajú s HDP alebo priamo počítajú zelený hrubý domáci produkt. Ekologická cena však zosúlad’uje biofyzikálnu hodnotu životného prostredia s jeho ekonomickou hodnotou a rozširuje schopnost' navrhovat' peňažné hodnoty pre prácu v životnom prostredí, ktoré sa majú použit' pri hodnotení alternatív riadenia, trhov 
služieb ekosystémov alebo pri formulovaní environmentálnej, či ekologickej politiky (Campbell, Marks, Con, 2020).

Oceňovanie ES s pevne stanovenými číselnými hodnotami má obmedzenia a výsledky hodnotenia neodrážajú faktory neistoty fungovania ekosystému. V riadení prírodných zdrojov pretrváva hl'adanie kompromisu medzi hospodárskym rastom a ochranou ekosystémov. Napr. v Č́íne väčšina miest eviduje ekologický deficit ako výsledok rastúceho dopytu po prírodných zdrojoch v porovnaní s ponukou prírodného kapitálu (Yang, Yang, Cheng, 2021). Pri rešpektovaní trhových princípov, obmedzením ponuky prírodného kapitálu, rastie jeho cena $\mathrm{v}$ čase, čo môže mat' dopad na celkovú ponuku a teda aj cenu všetkých tovarov a služieb, ktoré sú zdravé ekosystémy schopné poskytnút'.

V kvantitatívnom výskume ES dochádza ku kombinácií viacerých metód a modelov ako napríklad hodnota ekosystémovej služby (ESV), intervalové plánovanie parametrov (IPP), Dyna-CLUE a Monte Carlo, so zámerom vyvážit hodnotu ekosystémovej služby vo vzt'ahu k ekonomickým výhodám (Hu a kol., 2020). V praxi sú dostupné aj komplexnejšie modely monetárneho a nemonetárneho hodnotenia ES, ktoré ilustrujú možnosti krajiny poskytovat' ES v širšom rozsahu a kvalite pre rôzne budúce scenáre (obrázok 4). K najznámejším patria ARIES, InVEST, QuickScan, ESTIMAP a ESMERALDA.

Trhové nástroje využívané pri hodnotení ES sú považované za politické prostriedky, ktorých ciel'om je pozitívne stimulovat' starostlivost' o životné prostredie. Zarad'ujeme sem tie ekonomické nástroje, ktoré používajú ceny alebo iné ekonomické ukazovatele - napr. finančné stimuly na: redukovanie škôd, ochranu poškodzovania ekosystémov, podporu vhodnejších environmentálnych praktík (výnosovo orientované metódy, nákladovo orientované metódy; Chobotová, 2010).

Monetárne hodnotenie ES má svoje pozitíva aj negatíva. Hoci väčšina autorov jeho potrebu uznáva (najmä ako nástroja na zvyšovanie povedomia, prípadne na porovnanie nákladov rôznych alternatív pre zlepšenie poskytovania ES), čast' vedcov užitočnost' ekonomického hodnotenia ES spochybňuje. Napríklad podl’a Spangenberga a Setteleho (2010) monetárne hodnotenie ES nedokáže zachytit’ hodnotu ES v širšom zmysle a ignoruje tak ich sociálne a ekologické kvality, ktoré vnímajú príjemcovia ES na rôznych úrovniach. Norgaard (2000) uvádza, že monetárne metódy hodnotenia väčšinou iba pomáhajú vidiet' hodnoty ES z pohl'adu neudržatel’nej ekonomiky a nie z pohl'adu ,žiaduceho“ udržatel'ného ekonomického modelu. Často diskutovaný je aj etický rozmer hodnotenia služieb prírody (napr. Chan, Liao, 2016). Celkovo teda rezonuje potreba zasadit' ekonomické hodnotenie do 
širšieho kontextu hodnotenia ES ako podporného nástroja pre posun smerom k udržatel'nej spoločnosti.

ES vo vel'kej miere existujú mimo tradičné trhy. Tradičné hodnotenia sa zameriavajú na ekonomickú hodnotu ekosystémov, ktorú porovnávajú s HDP alebo priamo počítajú zelený hrubý domáci produkt. Ekologická cena však zosúlad’uje biofyzikálnu hodnotu životného prostredia s jeho ekonomickou hodnotou a rozširuje schopnost' navrhovat' peňažné hodnoty pre prácu v životnom prostredí, ktoré sa majú použit' pri hodnotení alternatív riadenia, trhov služieb ekosystémov alebo pri formulovaní environmentálnej, či ekologickej politiky (Campbell, Marks, Con, 2020).

Oceňovanie ES s pevne stanovenými číselnými hodnotami má obmedzenia a výsledky hodnotenia neodrážajú faktory neistoty fungovania ekosystému. V riadení prírodných zdrojov pretrváva hl'adanie kompromisu medzi hospodárskym rastom a ochranou ekosystémov. Napr. v Č́íne väčšina miest eviduje ekologický deficit ako výsledok rastúceho dopytu po prírodných zdrojoch v porovnaní s ponukou prírodného kapitálu (Yang, Yang, Cheng, 2021). Pri rešpektovaní trhových princípov, obmedzením ponuky prírodného kapitálu, rastie jeho cena v čase, čo môže mat’ dopad na celkovú ponuku a teda aj cenu všetkých tovarov a služieb, ktoré sú zdravé ekosystémy schopné poskytnút'.

V kvantitatívnom výskume ES dochádza ku kombinácií viacerých metód a modelov ako napríklad hodnota ekosystémovej služby (ESV), intervalové plánovanie parametrov (IPP), Dyna-CLUE a Monte Carlo, so zámerom vyvážit hodnotu ekosystémovej služby vo vzt'ahu k ekonomickým výhodám (Hu a kol., 2020). V praxi sú dostupné aj komplexnejšie modely monetárneho a nemonetárneho hodnotenia ES, ktoré ilustrujú možnosti krajiny poskytovat' ES v širšom rozsahu a kvalite pre rôzne budúce scenáre (obrázok 4). K najznámejším patria ARIES, InVEST, QuickScan, ESTIMAP a ESMERALDA. 


\section{Najznámejšie modely ekosystémových služieb}

-InVEST: súbor priestorových biofyzikálnych modelov na kvantifikáciu a hodnotenie úžitkov z ES vytvorený na Stanfordskej univerzite vhodný najmä na lokálnu a regionálnu úroveň (dostupné na internete: www.naturalcapitalproject.org). Niektoré modely sú určené aj na vyjadrenie monetárnej hodnoty ES.

- ESTIMAP: priestorový model použivaný najmä $\mathrm{v}$ kontinentálnej mierke avšak už $\mathrm{s}$ viacerými aplikáciami aj na národnej úrovni. Umožňuje hodnotenie vplyvu rôznych scenárov zmien využivania pôdy na poskytovanie ES. Na úrovni EÚ je funkčných osem analytických modelov zameraných na rôzne regulačné ES (napr. opel’ovanie, regulácia kvality ovzdušia), najčastejšie je však využivaný modul na hodnotenie rekreačných ES (Zulian a kol., 2018).

-QuickScan: ucelený softvérový priestorovo-štatistický nástroj určený na participatívne rozhodovanie zástupcov rôznych zainteresovaných skupín a subjektov za úč́asti odborníkov (Verweij a kol., 2016). Model môže byt' použitý na rôzne účely a $v$ rôznych mierkach (dostupné na internete: www.quickscan.pro).

-ESMERALDA: predstavuje 4 ročný projekt spolupráce financovaný z programu EÚ Horizont 2020. Je zameraná na poskytovanie ,flexibilnej metodológie ${ }^{u, ~ k t o r a ́ ~ p o s k y t u j e ~ z a ́ k l a d ~ p r e ~ c e l o e u r o ́ p s k e, ~}$ národné a regionálne mapovanie a hodnotenie ES a vytvára velké množstvo výskumných poznatkov a praktických riešení.

-ARIES: vyberá ekologické modely procesov tam, kde je to vhodné a zjednotušuje ich tam, kde modely neexistujú alebo sú nedostatočné. Všetky subjekty zapojené do interakcií medzi prírodou a spoločnost'ou prepojí do siete ekosystémových tokov a vytvorí najlepšie možné modely pre každý subjekt a vzájomnú interakciu. Výsledkom je podrobné, adaptívne a dynamické hodnotenie toho, ako príroda poskytuje l'ud'om benefity (dostupné na internete: www.aries.integratedmodelling.org).

Obrázok 4 Najznámejšie modely ekosystémových služieb

Zdroj: Vlastné spracovanie

\section{Záver}

Výsledky hodnotenia ekosystémových služieb monetárnym, nemonetárnym a kombinovaným spôsobom sa čoraz častejšie využívajú pri územnom plánovaní, cielenom manažmente ekosystémov, pri tvorbe strategických dokumentov, posudzovaní synergií a trade- off vzt’ahov medzi jednotlivými ES, ako aj pri nastavení priorít ich využívania. Hlavný pokrok vo výskume a aplikácii konceptu ES je v prechode od definícií ku klasifikáciám a hodnoteniu ES, $\mathrm{v}$ prechode od integrovaného modelovania $\mathrm{k}$ verejnej participácii a komunikácii a k vývoju inštitúcií a inovácií v riadení spoločnosti (Costanza et al., 2017).

Z hl'adiska použitých metód a prístupov boli publikované viaceré rôznorodé metodiky hodnotenia ES, avšak stále je mnoho oblastí, ktoré nie sú adekvátne definované. Nedostatočné je napr. dokumentovanie a výskum pozitívneho prepojenia pôdnej biodiverzity s regulačnými a produkčnými službami (Bakker et al., 2019) alebo hodnotenie využívania niektorých ES ako napr. asimilácia znečist’ujúcich látok v mokradiach (Trimmer et al. 2019). Rastúci počet dôkazov o pozitívnom dopade prírodného prostredia na mentálne zdravie poukazuje na potrebu zahrnutia modelov pre hodnotenie ES aj v tejto oblasti (Bratman et al. 2019). Ďalšou zaujímavou oblast’ou sú priestorové toky ES a ich vzájomné vzt’ahy v lokálnom až globálnom meradle (napr. Schipke, 2019). Výskum zameraný na hodnotenie a oceňovanie ES bude neustále potrebovat' kvalitné dáta o ekosystémoch $\mathrm{v}$ rôznych územiach. $\mathrm{V}$ rámci výskumu $\mathrm{ES}$ 
možno očakávat' čoraz intenzívnejšie kombinovanie spoločenských a prírodných vied, ktoré majú perspektívu objavovat' nové pohl'ady a prístupy $\mathrm{k}$ hodnoteniu $\mathrm{ES}$, zohl'adňujúc dôležitost' ich zachovania pre budúce generácie.

Grantová podpora: Článok je súčast’ou riešenia projektu APVV-18-0035 Oceňovanie ekosystémových služieb prírodného kapitálu ako nástroja hodnotenia sociálno-ekonomického potenciálu území.

\section{Zoznam použitej literatúry}

[1] Badura T., Ferrini S., Agarwala M., \& Turner K. (2017). Valuation for Natural Capital and Ecosystem Accounting. [Oceňovanie pre prírodný kapitál a ekosystémové účtovníctvo]. Norwich, UK: University of East Anglia.

[2] Bakker, M. R. et al. (2019). Belowground Biodiversity Relates Positively to Ecosystem Services of European Forests. [Podzemná biodiverzita má pozitívny vzt'ah k ekosystémovým službám európskych lesov]. Frontiers in Forrest and Global Change, 19. https://doi.org/10.3389/ffgc.2019.00006.

[3] Bakshi, B. R. (2002). A Thermodynamic Framework for Ecologically Conscious Process Systems Engineering. [Termodynamický rámec pre ekologické inžinierstvo procesných systémov]. Computer Chemical Engeneering, 26, DOI 10.1016/s0098-1354(01)00745-1.

[4] Banerjee, O. et al. (2020). Global socio-economic impacts of changes in natural capital and ecosystem services: State of play and new modeling approaches. [Globálne sociálnoekonomické dopady zmien prírodného kapitálu a ekosystémových služieb: Súčasný stav a nové prístupy k modelovaniu]. Ecosystem Services, 46, 101202. DOI 10.1016/j.ecoser.2020.101202.

[5] Brand, A. F. et al. (2020). Biological and anthropogenic predictors of metal concentration in the Eurasian otter, a sentinel of freshwater ecosystems. [Biologické a antropogénne prediktory koncentrácie kovov vo vydre Eurázijskej, stráži sladkovodných ekosystémov]. Environmental Pollution, 266(3), 1-9. DOI 10.1016/j.envpol.2020.115280.

[6] Bratman, G. N. et al. (2019). Nature and mental health: An ecosystem service perspective. [Príroda a duševné zdravie: perspektíva ekosystémových služieb]. Science Advances, 5(7), DOI: 10.1126/sciadv.aax0903.

[7] Burkhard, B., Kandziorai, M. S., \& Muller, F. (2014). Ecosystem Service Potentials, Flows and Demands - Concepts for Spatial Localisation, Indication and Quantification. [Potenciály, toky a požiadavky ekosystémových služieb - koncepty priestorovej 
lokalizácie, indikácie a kvantifikácie]. Landscape Online, 34, 1-32. DOI 10.3097/LO.201434.

[8] Campbell, E., Marks, R., \& Conn, Ch. (2020). Spatial modeling of the biophysical and economic values of ecosystem services in Maryland, USA. [Priestorové modelovanie biofyzikálnych a ekonomických hodnôt ekosystémových služieb v Marylande, USA]. Ecosystem Services, 43, 101093. DOI 10.1016/j.ecoser.2020.101093.

[9] Costanza , R. et al. (2017). Twenty years of ecosystem services: How far have we come and how far do we still need to go? [Dvadsat' rokov ekosystémových služieb: Ako d'aleko sme sa dostali a ako d’aleko ešte musíme zájst??]. Ecosystem Services, 28, 1-16. https://doi.org/10.1016/j.ecoser.2017.09.008.

[10]Costanza, R. et al. (1997). The Value of the World's Ecosystem Services and Natural Capital. [Hodnota svetových ekosystémových služieb a prírodného kapitálu.]. Nature, 387. 253-260. DOI 10.1016/S0921-8009(98)00020-2.

[11] Costanza, R., De Groot, R., Sutton, P., Van der Ploeg, S., J. Anderson, S., Kubiszewski, I., Farber, S., R., \& Turner, K. (2014). Changes in the global value of ecosystem services. [Zmeny v globálnej hodnote ekosystémových služieb]. Global Environmental Change, 26, 152-158. https://doi.org/10.1016/j.gloenvcha.2014.04.002.

[12] Crossman, N. D., \& Bryan, B. A. (2009). Identifying cost-effective hotspots for restoringnatural capital and enhancing landscape multi-functionality. [Identifikácia nákladovo efektívnych hotspotov na obnovu prírodného kapitálu a zlepšenie multifunkčnosti krajiny]. Ecological Economics, 68, 654-668. https://doi.org/10.1016/j.ecolecon.2008.05.003.

[13]Černecký, J., Gajdoš, P., Ďuricová, V., Špulerová, J., Černecká, L., Švajda, J., Andráš, P., Ulrych, L., Rybanič, R., \& Považan, R. (2020). Hodnota ekosystémov a ich služieb na Slovensku. Banská Bystrica, SK: ŠOP SR.

[14]De Groot, R. S., Wilson, M. A., \& Boumans, R. M. J. (2002). A typology for the classification, description and valuation of ecosystem functions, goods and services. [Typológia na klasifikáciu, popis a hodnotenie funkcií, tovarov a služieb ekosystémov]. Ecological Economics, 41(3), 393-408. DOI 10.1016/S0921-8009(02)00089-7.

[15]De Groot, R., Brander, L., Van der Ploeg, S., Costanza, R., Bernard, F., Braat, L., Christie, M., Crossman, N., Ghermandi, A., Hein, L., Hussain, S., Kumar, P., McVittie, A., Portela, R., Rodriguez, L.C., Brink, P., \& Van Beukering , P. (2012). Global estimates of the value of ecosystems and their services in monetary units. [Globálne odhady 
hodnoty ekosystémov a ich služieb v peňažných jednotkách.]. Ecosystem Services, 1(1), 50-61. DOI 10.1016/j.ecoser.2012.07.005.

[16]Dominati, E. J., Patterson, M. G., \& Mackay, A. D. (2010). Response to Robinson and Lebron - Learning from complementary approaches to soil natural capital and ecosystem services. [Reakcia na Robinsona a Lebrona - Učenie sa z komplementárnych prístupov k prírodnému kapitálu pôdy a ekosystémovým službám]. Ecological Economics, 70(2), 139-140. DOI 10.1016/j.ecolecon.2010.10.002.

[17]Farley, J., Costanza, R., Flomenhoft, G., \& Kirk, D. (2014). The Vermont common assets trust: an institution for sustainable, just and efficient resource allocation. [Vermontský fond spoločných aktív: inštitúcia pre udržatel'né, spravodlivé a efektívne pridel'ovanie zdrojov]. Ecological Economics, 109, 71-79. DOI 10.1016/j.ecolecon.2014.10.016.

[18]Finnveden, G. et al. (2009). Recent developments in Life Cycle Assessment. [Najnovší vývoj v hodnotení životného cyklu]. Journal of Environmental Management, 91(1), 1-21. DOI 10.1016/j.jenvman.2009.06.018.

[19] Gómez-Baggethum, E., \& Groot, R. (2010). Natural capital and ecosystem services: The ecological foundation of human society. [Prírodný kapitál a ekosystémové služby: Ekologický základ l'udskej spoločnosti]. International Journal of Web Based Communities - IJWBC. DOI 10.1039/9781849731058-00105.

[20]Heckwolf, M., J. et al. (2021). From ecosystems to socio-economic benefits: A systematic review of coastal ecosystem services in the Baltic Sea. [Od ekosystémov k sociálno-ekonomickým výhodám: Systematický prehl’ad služieb pobrežných ekosystémov v Baltskom mori]. Science of The Total Environment, 755(2), 142565. DOI 10.1016/j.scitotenv.2020.14256.

[21]Horlings, E., Schenau, S., Hein, L., Lof, M., de Jongh, L., \& Polde, M. (2020). Experimental monetary valuation of ecosystem services and assets in the Netherlands. [Experimentálne peňažné ocenenie ekosystémových služieb a aktív v Holandsku]. Hague, NL: Wageningen University \& Research.

[22]Hu, M., Wang, Y., Xia, B., Jiao, M., \& Huang, G. (2020). How to balance ecosystem services and economic benefits? - A case study in the Pearl River Delta, China. [Ako vyvážit' ekosystémové služby a ekonomické výhody? - Prípadová štúdia v delte Perlovej rieky v Číne]. Journal of Environmental Management, 271, 110917. DOI 10.1016/j.jenvman.2020.110917.

[23]Chan, L. (2016). What is ecological wisdom and how does it relate to ecological knowledge? [Čo je ekologická múdrost' a ako súvisí s ekologickým poznaním?]. 
Landscape Urban Planning, 155, 111-113. https://doi.org/10.1016/j.landurbplan.2016.07.006.

[24]Chobotová, V. (2010). Trhový prístup k ekosystémovým službám. Životné prostredie, 44(2), 92-95.

[25]Kanianska, R., Jad’ud’ová, J., Makovníková, J., Kizeková, M., \& Tomaškin, J., (2016). Ekosystémové služby. Banská Bystrica, SK: Belianum. Vydavatel'stvo Univerzity Mateja Bela v Banskej Bystrici.

[26] Kubiszewski et al. (2017). The future value of ecosystem services: Global scenarios and national implications. [Budúca hodnota ekosystémových služieb: Globálne scenáre a národné dôsledky]. Ecosystem Services, 26, 289-301, https://doi.org/10.1016/j.ecoser.2017.05.004

[27]MAE. (2005). Ecosystems and Human Well-being. [Ekosystémy a l'udské blaho]. World Resoursec Instutute.

[28] Makovníková et al. (2019). Teoreticko-metodologické aspekty hodnotenia a oceňovania agroekosystémových služieb. Ekonomika a spoločnost', 20(2), 42-52, ISSN 1335-7069.

[29] Mederly, P., Černecký, J., et al. (2019). Katalóg ekosystémových služieb Slovenska. Banská Bystrica, SK: ŠOP SR, UKF v Nitre, ÚKE SAV.

[30]Moravčík, M., Čaboun, V., Tutka, J., et al. (2008). Výskum, klasifikácia a uplatňovanie funkcií lesa v krajine: Správa pre priebežnú oponentúru úlohy výskumu a vývoja. Zvolen, SK: Národné lesnícke centrum.

[31] Norgaard, R. B. (2010). Ecosystem services: From eye-opening metaphor to complexity blinder. [Ekosystémové služby: Od metafory, ktorá otvára oči, až po zložitost']. Ecological Economy, 69(6), 1219-1227. https://doi.org/10.1016/j.ecolecon.2009.11.009.

[32] Pandey, L. K., \& Bergey, E. A. (2016). Exploring the status of motility, lipid bodies, deformities and size reduction in periphytic diatom community fromchronically metal $(\mathrm{Cu}, \mathrm{Zn})$ polluted waterbodies as a biomonitoring tool. [Skúmanie stavu motility, lipidových teliesok, deformácií a zmenšenia vel'kosti v spoločenstve perifytických rozsievok $\mathrm{z}$ vodných útvarov chronicky kovmi $(\mathrm{Cu}, \mathrm{Zn})$ znečistených ako nástroj biomonitorovania.]. Science of Total Environment, 550, 372-381. DOI: 10.1016/j.scitotenv.2015.11.151.

[33] Považan, R. (2013). Rekreačné hodnoty NP Vel'ká Fatra. Acta Universitatis Matthiae Belii Environmental management Series, 15(1), 82-94.

[34] Santos-Martin, F., Viinikka A, Mononen, L., Brander, L., Vihervaara, P., Liekens, I., \& Young, P. M. (2018). Creating an operational database for Ecosystems Services Mapping 
and Assessment Methods. [Vytvorenie operačnej databázy pre metódy mapovania a hodnotenia ekosystémových služieb]. One Ecosystem, 3 https://doi.org/10.3897/oneeco.3.e26719.

[35] Seják, J., Dejmal, I., Petŕiček, V., Cudlín, P., Míchal, I., Černý, K., Kučera, T. et al. (2003). Hodnocení a oceňovaní biotopů České republiky. Praha. Dostupné na: http://fzp.ujep.cz/projekty/vav-610-5-01/hodnocenibiotopucr.pdf

[36] Seppelt, R., Manceur, A. M., Liu, J., Fenichel, E. P., \& Klotz, S. (2014). Synchronized peak-rate years of global resources use. [Synchronizované špičkové roky využívania globálnych zdrojov]. Ecology and Society, 19(4), 50. http://dx.doi.org/10.5751/ES07039-190450.

[37] Schipke, T. (2019). The Experience of Home-based Palliative Care Patients Who Are Transitioning from Sickness to Dying. [Skúsenosti pacientov domácej paliatívnej starostlivosti, ktorí prechádzajú z choroby do smrti]. California Institute of Integral Studies. ProQuest Dissertations Publishing.

[38] Spangeberg, J. H., \& Settele, J. (2010). Precisely incorrect? Monetising the value of ecosystem services. [Presne nesprávne? Monetizácia hodnoty ekosystémových služieb]. Ecological Complexity, 7(3), 327-337. https://doi.org/10.1016/j.ecocom.2010.04.007.

[39] TEEB (2010). The Economics of Ecosystems and Biodiversity Ecological and Economic Foundations. [Ekonomika ekosystémov a biodiverzity Ekologické a ekonomické základy]. Earthscan: London and Washington.

[40] Trimmer, M., Zhu, Y., Purdy, K., Eyice, Ö., Shen, L., Harpenslager, S., Yvon-Durocher, G., \& Dumbrell, A. ( 2020 ). Disproportionate increase in freshwater methane emissions induced by experimental warming. [Neúmerné zvýšenie emisií sladkovodného metánu vyvolané experimentálnym otepl'ovaním]. Nature Climate Change, 10, 685-690. https://doi.org/10.1038/s41558-020-0824-y.

[41]Tutka, J., Kovalčík, \& M., Sarvašová, Z. (2011). Hodnotenie verejnoprospešných funkcií lesných ekosystémov : metódy a metodické prístupy. Zvolen, SK: Národné lesnícke centrum - Lesnícky výskumný ústav Zvolen.

[42] Verweij, P. et al. (2016). QUICKScan as a quick and participatory methodology for problem identification and scoping in policy processes. [QUICKScan ako rýchla a participatívna metodológia na identifikáciu problémov a rozsah v procesoch politiky]. Environmental Science and Policy, 66, https://doi.org/10.1016/j.envsci.2016.07.010. 
[43] Wackernagel, M., Monfreda, C., Moran, D., Wermer, P., Goldfinger, S., Deumling, D., \& Murray, M. (2005). National Footprint and Biocapacity Accounts 2005: The underlying calculation method. [Účty národnej stopy a biokapacity 2005: Základná metóda výpočtu]. Oakland, CA: Global Footprint Network.

[44]Welde, K., \& Gebremariam, B. (2017). Effect of land use land cover dynamics on hydrological response of watershed: Case study of Tekeze Dam watershed, northern Ethiopia. [Vplyv dynamiky využívania krajiny na hydrologickú odozvu povodia: Prípadová štúdia povodia priehrady Tekeze, severná Etiópia]. International Soil and Water Conservation Research, 5, 1-16. DOI 10.1016/j.iswcr.2017.03.002.

[45] Yang, Y., Yang, H., Cheng, Y. (2021). Why is it crucial to evaluate the fairness of natural capital consumption in urban agglomerations in terms of ecosystem services and economic contribution? [Prečo je kl'účové hodnotit' spravodlivost' spotreby prírodného kapitálu v mestských aglomeráciách z hl'adiska ekosystémových služieb a ekonomického prínosu?]. Sustainable Cities and Society, 65, 102644. DOI 10.1016/j.scs.2020.102644.

[46]Zanchi, G., \& Brady, M. (2019). Evaluating the contribution of forest ecosystem services to societal welfare through linking dynamic ecosystem modelling with economic valuation. [Hodnotenie prínosu služieb lesných ekosystémov k blahobytu spoločnosti prostredníctvom prepojenia dynamického modelovania ekosystémov s ekonomickým hodnotením]. Ecosystem Services. 39. DOI 101011. 10.1016/j.ecoser.2019.101011.

[47]Zulian, G. et al. (2018). Practical application of spatial ecosystem service models to aid decision support. [Praktická aplikácia modelov priestorových ekosystémových služieb na podporu rozhodovania]. Ecosystem Services, 29, 465-480. https://doi.org/10.1016/j.ecoser.2017.11.005.

Adresa autorov: Bc. Bianka Slašt’anová, Ekonomická fakulta UMB, Tajovského 10, Banská Bystrica, Slovensko, bianka.slastanova@student.umb.sk; doc. Ing. Stanislav Kološta, PhD., Ekonomická fakulta UMB, Tajovského 10, Banská Bystrica, Slovensko, stanislav.kolosta@umb.sk; RNDr. Jarmila Makovníková, CSc., VÚPOP - Regionálne pracovisko Banská Bystrica, Mládežnícka 36, 97404 Banská Bystrica, Slovensko, jarmila.makovnikova@nppc.sk. 